\title{
The Polymerase Chain Reaction in Diagnosis of Small B-Cell Non-Hodgkin Lymphomas
}

\author{
Ester Lianawati Antoro, Ery Kus Dwianingsih, Indrawati, FX Ediati Triningsih*, \\ Harijadi
}

\begin{abstract}
Background: Small B-cell non-Hodgkins lymphoma (NHL) is difficult to be distinguished from non-neoplastic reactive processes using conventional haematoxylin-eosin (HE) staining due to different interpretations among pathologists with diagnosis based on morphologic features. Ancillary examinations such as immunohistochemical (IHC) staining are essential. However, negative or doubtful results are still sometimes obtained due to unsatisfactory tissue processing or IHC technique. The polymerase chain reaction (PCR) as a molecular diagnostic technique is very sensitive and specific. Clonality detection of heavy chain immunoglobulin (IgH) gene rearrangement has been widely used to establish diagnosis of B-cell NHL. Aims: To elaborate interobserver variation in small B-cell NHL diagnosis based on morphologic features only and to confirm sensitivity and specificity of the PCR technique as an ancillary method. Materials and Methods: A toptal of 28 samples of small B cell NHL and suspicious lymphoma were interpreted by 3 pathologists in Sardjito General Hospital based on their morphology only. The reliability of assessment and the coefficient of interobserver agreement were calculated by Fleiss kappa statistics. Interpretation results were confirmed with $\mathrm{IHC}$ staining $(\mathrm{CD20}, \mathrm{CD3}, \mathrm{Bcl} 2)$. PCR was performed to analyze the clonality of IgH gene rearrangement. Results: Interobserver agreement in morphologic evalution of small B cell NHL and chronic lymphadenitis revealed kappa coefficient 0.69 included in the substantial agreement category. The cases were divided into 3 groups based on morphology and IHC results; lymphoma, reactive process and undetermined group. PCR analysis showed $90 \%$ sensitivity and $60 \%$ specificity. Conclusions: The present study revealed a substantial agreement among pathologists in small B-cell NHL diagnosis. For difficult cases, PCR is useful as complementary method to morphologic and IHC examinations to establish definitive diagnosis.
\end{abstract}

Keywords: Small B-cell non-Hodgkins lymphoma - immunohistochemistry - heavy chain immunoglobulin - PCR

Asian Pac J Cancer Prev, 17 (2), 491-495

\section{Introduction}

The incidence of lymphoma, especially B-cell lymphomas, is increasing worldwide, with more than 280.000 cases occurring annually each year (Jaffe ES et al., 2008). In Canada and Lebanon, it represents fifth most frequent cancer (Ferley et al., 2013; Sader-Ghorra et al., 2014). The etiology of Non Hodgkin Lymphoma (NHL), which is the most common, remains unknown exactly, however some infectious agents, such as EBV, have been shown to contribute the lymphomagenesis. In one Pakistan study, the frequency of EBV in NHL was 12,7\% (Ishtiaq et al., 2013).

The diagnosis of lymphoid neoplasms had transitioned over the years from a purely morphology-based approach to a system integrating immunologic and molecular biology finding. Some lymphomas are often difficult to be distinguished from reactive processes based on routine $\mathrm{HE}$ staining only, especially when the specimens is too small, or there are some prominent artefact and necrosis (Kitamura et al., 1996). Small B-cell non-Hodgkin lymphoma (NHL), which comprise more than $30 \%$ of NHL, is difficult to be distinguished from non-neoplastic reactive process, notably small lymphocytic lymphoma (SLL), follicular lymphoma (FL) low grade and extranodal marginal zone B cell lymphoma (ENMZL) (Rizzo and Nassiri, 2012). The reactive process which morphologically mimicking lymphoma are: follicular hyperplasia, progressively transformed germinal centre (PTGC), hyaline vascular Castleman's disease (HVCD), mantle zone hyperplasia (MZH) and Kikuchi necrotizing lymphadenitis (KNL) (His and Schnitzer, 2011; Rosai, 2011). The difficulties of making the diagnosis is mainly due to a similarity of the histopatologic features. It can cause different interpretation among pathologists to diagnose based on $\mathrm{HE}$ staining only. As previously reported, follicular lymphoma (FL) gastrointestinal were $18,8 \%$ misdiagnosed by pathologists based on histopathologic features (Iwamuro

Department of Anatomical Pathology, Faculty of Medicine, Universitas Gadjah Mada, Yogyakarta, Indonesia *For correspondence: fxediatitriningsih@yahoo.com 
et al., 2014). Another studies revealed that there was interobserver variation in classifying lymphoma and the interobserver reproducibility in the morphologic evaluation gastric mucosa associated lymphoid tissue (MALT) lymphoma was suboptimal (El-Zimaity et al., 2005; Pongpruttipan et al., 2014). Therefore, ancillary examination such as immunohistochemical (IHC) staining is essential to be conducted. However, negative or doubtful result is sometimes obtained due to unsatisfying tissue processing or poor immunohistochemistry technique. Besides, the loss of antigenity influenced by many factors can cause false negative result (Xie et al., 2011). In the majority of lymphoproliferative disorders, histopathology examination with IHC can distinguish between benign and malignant. However, there are $10-15 \%$ cases need clonality analysis to establish definitive diagnosis (Langerak et al., 2012). PCR has meanwhile been accepted as the method for the assessment of B-cell clonality. In the most studies, PCR methods were designed to amplify IgH gene rearrangements. Its sensitivity of determining clonality is variable from $85 \%-99 \%$ based on the type of primer used and method in determining PCR products (Campo et al., 2011; Taheri et al., 2011). The investigation of gene expression profiling of NHL have been conducted and revealed a new differentially expressed gene that can be a marker for NHL patients (Zekri et al., 2013). This study is conducted to elaborate the interobserver variation in small B-cell NHL diagnosis based on morphologic features only and to confirm sensitivity and specificity of PCR as an ancillary method to diagnose small B-cell NHL.

\section{Materials and Methods}

\section{Case Material}

This study recruited cases with original diagnosis of small B-cell non Hodgkin lymphoma and chronic lymphadenitis. Each case has been diagnosed by general pathologist based on evaluation of HE-stained. Twenty eight cases in the period January 2011 through February 2014 were obtained, consisting of 19 SLL, 3 FL, 2 malt lymphoma, 1 ENMZL and 3 chronic lymphadenitis. The selected cases had the following charactheristics : the slide was taken from small biopsies which consist of immature and atypic limfoid cells, arranged in diffuse, follicular or pseudofollicular pattern, cells size were bigger than mature lymphocyte but smaller than macrophage and endothelial cells, and the nuclei were round, irregular or cleaved.

\section{Observers}

The observers are 3 pathologists in Sardjito General Hospital, Yogyakarta, Indonesia, who have the same experiences on expertising small biopsies from lymph nodes.

\section{Morphological Review}

All routine HE-stained slides were reviewed by each observer to determine whether it is benign or malignant. All observers were blinded to the clinical data and other information of the cases. Agreement among pathologists was analyzed using kappa statistics.

\section{Immunohistochemical Review}

The cases were divided into 3 groups according to morphology and immunohistochemical features. Group 1 were cases with clear characteristic of lymphoma, manifesting as diffuse positive staining of CD20 in cytoplasmic B cell lymphoid, scattered positive staining of CD3 in cytoplasmic $\mathrm{T}$ cell reactive and positive staining of BCL2 in germinal centre (GC) of follicular lymphoma. Group 2 were cases with clear characteristic of non-malignant reactive process, manifesting as positive staining of CD 20 in germinal centre and mantle zone, positive staining of CD3 in paracortex and reactive T cell within GC, positive staining of BCL2 in mantle zone and some intrafollicular T cells (Campo et al., 2011). Group 3 were cases with undetermined or inconclusive decision based on IHC result.

\section{DNA Extraction, PCR conditions and Primers}

Genomic DNA was extracted from Formalin Fixed Paraffin Embedded (FFPE) tissue with DNA extraction kit from NucleoSpin. Extracted DNA was kept at $-20^{\circ} \mathrm{C}$. All of the 28 cases were investigated for B-cell clonality by semi-nested PCR using specific primers previously used, directed against Framework II (FR II) and Framework III (FRIII) regions of IgH genes (Table 1) (Amara et al,, 2006). The PCR reaction mixture contained $1 \mu \mathrm{L}$ genomic DNA, $7.4 \mu \mathrm{L} \mathrm{H}_{2} \mathrm{O}, 10 \mu \mathrm{L}$ kappa 2 tag ready mix, $0.8 \mu \mathrm{L}$ each of the FR2A or FR3A and LJH or VLJH primers. The cycling conditions were 5 minutes at $93^{\circ} \mathrm{C}$ for denaturation, followed by 35 cycles of $93^{\circ} \mathrm{C}$ for 1 minute, $56^{\circ} \mathrm{C}$ for 30 seconds and $72^{\circ} \mathrm{C}$ for 1 minute. The final extension was $72^{\circ} \mathrm{C}$ for 1 minute. Each PCR product was analyzed by electrophoresis in a $4 \%$ agarose gel containing ethidium bromide. Electrophoresis was performed at $75 \mathrm{~V}$ for approximately 2 hours in $30 \mathrm{~cm}$-long gel.

After electrophoresis, gels were removed from the plate and visualized under UV light. The 50bp DNA step ladder was used as a DNA marker. PCR reactions were performed twice, including negative and positive control. Clonal pattern were assigned when identical band(s) one or two depending on whether one or both alleles were rearranged, were observed in duplicate in the appropriate size range (reproducible band). Polyclonal patterns were characterized by the presence of either a broad smear or multiple bands in the gels (Amara et al., 2006; Taheri et al., 2011).

Table 1. Nucleotide Sequences of Primers Used in PCR Amplification

\begin{tabular}{|c|l|l|}
\hline $\begin{array}{c}\text { Gene } \\
\text { targeted }\end{array}$ & Primer & \multicolumn{1}{c|}{ Sequence (5'à --> 3') } \\
\hline \multirow{5}{*}{ IgH } & FRIIa & $\begin{array}{l}\text { TGG (A/G)TC CG(C/A) CAG (G/C) } \\
\text { C(T/C) CNG G }\end{array}$ \\
\cline { 2 - 3 } & FRIIIa & $\begin{array}{l}\text { ACA GGG C(C/T)(G/C) TGT ATT } \\
\text { ACT GT }\end{array}$ \\
\cline { 2 - 3 } & LJH & TGA GGA GAC GGT GAC C \\
\cline { 2 - 3 } & VLJH & $\begin{array}{l}\text { GTG ACC AGG GTN CCT TGG CCC } \\
\text { CAG }\end{array}$ \\
\hline
\end{tabular}




\section{Results}

Morphology interpretation by observers

The samples obtained from twenty-eight cases consist of 11 females and 17 males with range age 5 - 79 years old. All the pathologists had an agreement diagnosis on 17 cases, whereas another 11 cases had disagreement. The category of interobserver agreement among 3 pathologists in distinguish malignant and benign lesion was substantial agreement with $x=0.69$.
PCR in Diagnosis of Small B-Cell Non-Hodgkins Lymphomas Feasibility of DNA extraction and IgH-PCR

Genomic DNA was successfully extracted in all FFPE samples with high concentration of DNA. The PCR products was yielded by amplification of FRIII and FII region using specific primers of the $\operatorname{IgH}$ gene, with expected range size $60-120$ base pair and 200-300 base pair, respectively (Figures 1 and 2). Negative and smear patterns would be considered as polyclonality, whereas single or dual discrete bands indicated monoclonality of cases.

Table 2. Clinico-pathologic Data, HE, IHC and Clonality Results

\begin{tabular}{|c|c|c|c|c|c|c|}
\hline \multirow{2}{*}{ Case Number } & \multirow{2}{*}{ Age (years) } & \multirow{2}{*}{ Sex } & \multirow{2}{*}{ Organ } & \multirow{2}{*}{ HE \& IHC } & \multicolumn{2}{|c|}{ PCR } \\
\hline & & & & & FRIIA & FRIIIA \\
\hline 1 & 34 & $\mathrm{~L}$ & Orbita & NL & $\mathrm{P}$ & M \\
\hline 2 & 71 & $\mathrm{~L}$ & Vertebra & $\mathrm{L}$ & $\mathrm{P}$ & $\mathrm{P}$ \\
\hline 3 & 5 & $\mathrm{P}$ & Lymph node & NL & M & $\mathrm{P}$ \\
\hline 4 & 52 & $\mathrm{~L}$ & Lymph node & NL & $\mathrm{P}$ & $\mathrm{P}$ \\
\hline 5 & 55 & $\mathrm{P}$ & Lymph node & ND & $\mathrm{P}$ & M \\
\hline 6 & 40 & $\mathrm{~L}$ & Tonsil & ND & $\mathrm{P}$ & M \\
\hline 7 & 45 & $\mathrm{~L}$ & Lymph node & NL & $\mathrm{P}$ & $\mathrm{P}$ \\
\hline 8 & 70 & $\mathrm{~L}$ & Submandibular & $\mathrm{L}$ & M & M \\
\hline 9 & 71 & $\mathrm{~L}$ & Nasopharinx & ND & M & M \\
\hline 10 & 65 & $\mathrm{P}$ & Orbita & $\mathrm{L}$ & $\mathrm{P}$ & M \\
\hline 11 & 38 & $\mathrm{P}$ & Lymph node & NL & $\mathrm{P}$ & $\mathrm{P}$ \\
\hline 12 & 59 & $\mathrm{~L}$ & Lymph node & $\mathrm{L}$ & M & M \\
\hline 13 & 50 & $\mathrm{P}$ & Mandibula & $\mathrm{L}$ & M & $\mathrm{P}$ \\
\hline 14 & 48 & $\mathrm{P}$ & Conjungtiva & $\mathrm{L}$ & M & M \\
\hline 15 & 41 & $\mathrm{P}$ & Lymph node & $\mathrm{L}$ & $\mathrm{P}$ & M \\
\hline 16 & 74 & $\mathrm{~L}$ & Conjungtiva & $\mathrm{L}$ & M & $\mathrm{P}$ \\
\hline 17 & 33 & $\mathrm{P}$ & Ileocecal & $\mathrm{L}$ & M & $\mathrm{P}$ \\
\hline 18 & 56 & $\mathrm{~L}$ & Lymph node & $\mathrm{L}$ & $\mathrm{P}$ & M \\
\hline 19 & 48 & $\mathrm{~L}$ & Submandibular & $\mathrm{L}$ & $\mathrm{P}$ & $\mathrm{P}$ \\
\hline 20 & 79 & $\mathrm{~L}$ & Palpebra & $\mathrm{L}$ & $\mathrm{P}$ & M \\
\hline 21 & 75 & $\mathrm{~L}$ & Retrobulbar & $\mathrm{L}$ & $\mathrm{P}$ & M \\
\hline 22 & 45 & $\mathrm{~L}$ & Lymph node & $\mathrm{L}$ & M & M \\
\hline 23 & 51 & $\mathrm{~L}$ & Stomach & $\mathrm{L}$ & $\mathrm{P}$ & M \\
\hline 24 & 67 & $\mathrm{~L}$ & Colon & $\mathrm{L}$ & $\mathrm{P}$ & M \\
\hline 25 & 70 & $\mathrm{P}$ & Lymph node & $\mathrm{L}$ & M & M \\
\hline 26 & 57 & $\mathrm{P}$ & Lacrimal Gland & $\mathrm{L}$ & $\mathrm{P}$ & M \\
\hline 27 & 50 & $\mathrm{~L}$ & Lymph node & $\mathrm{L}$ & $\mathrm{P}$ & M \\
\hline 28 & 70 & $\mathrm{P}$ & Lymph node & $\mathrm{L}$ & $\mathrm{P}$ & $\mathrm{M}$ \\
\hline
\end{tabular}

$\mathrm{L}=$ lymphoma; $\mathrm{NL}=$ non lymphoma; $\mathrm{ND}=$ not determined; $\mathrm{M}=$ Monoclonal; $\mathrm{P}=$ Polyclonal

Table 3. PCR Results Related to Morphologic and Immunohistochemical Analysis Result

\begin{tabular}{|l|c|c|c|}
\hline \multirow{2}{*}{} & \multicolumn{3}{|c|}{ Morphologic and IHC Result } \\
\cline { 2 - 4 } & Positive & Negative & Undetermined \\
\hline PCR Result & (Group I ) & (Group II ) & 3 \\
\hline PCR Monoclonal & 18 & 2 & 0 \\
\hline PCR Polyclonal & 2 & 3 & 3 \\
\hline Total cases & 20 & 5 & III ) \\
\hline
\end{tabular}




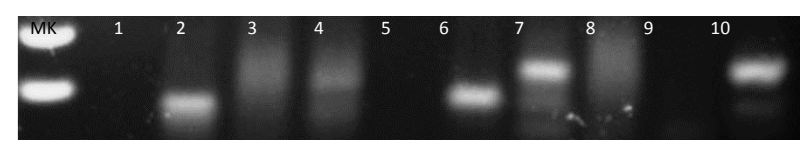

Figure 1. PCR result of FRIII, 60-120 bp. Lane 1 indicates negative control. Lane 2 indicates positif control. Lane 3,4, 5 and 9 show polyclonal pattern. Lane 6, 7, and 10 show monoclonal pattern. MK indicates marker

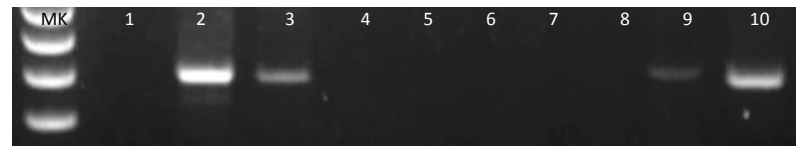

Figure 2. PCR result of FRII, 200-300 bp. Lane 1 indicates negative control. Lane 2 indicates positif control. Lane 3,9, and 8 show monoclonal pattern. Lane 4,5,6,7, and 8 show polyclonal pattern. MK indicates marker

Correlation of PCR Results with Morphologic and Immunohistochemical Diagnoses

Table 2 shows clinical data, biopsy location, IHC result and PCR result of the 28 samples. A monoclonal IgH gene rearrangement was identified in $90 \%$ (18/20) of the samples in group I which was defined as morphologically and immunohistochemically positive for lymphoma. 15 samples showed monoclonal with primer FRIII, 8 samples with primer FRII and 18 were both positive. In group 2 , a monoclonal (reproducible band) was observed in $40 \%(2 / 5)$ of the specimens that were morphologically and immunohistochemically not lymphoma. All cases in group 3 which have undetermined IHC result showed monoclonal band, as shown in table 3 .

\section{Discussion}

This study was designed to evaluate the interobserver agreement to distinguish small B-cell NHL from reactive process based on morphologic feature only. This study obtained a substantial agreement among 3 pathologists with $x=0.69$ (Viera and Garrett, 2005). This result is higher than similar previous study with gastric malt lymphoma as samples (El-Zimaity et al., 2005). Farmer et al., showed that kappa scored for CLL and MCL diagnosis in small tissue among pathologists was nearly 1 , whereas the lowest kappa score were obtained from FL and MZL (Farmer et al., 2007).

There were 11 cases (39.3\%) which had a disagreement among pathologists, thus an ancillary study was needed to improve diagnosis accuracy. In Sardjito General Hospital, IHC examination is routinely conducted as a complementary examination to HE staining. Nevertheless, in some cases with undetermined result, IHC can not be used to establish the diagnosis. There were 3 samples with doubtful and undetermined IHC results. This could be caused by inadequate fixation time, improper processing procedure, inadequate tissue dehydration before paraffin embedding and inappropriate storage humidity resulting antigen degradation (Werner et al., 2000; Xie et al., 2011).

Clonality analysis of IgH gene rearrangement has become an important method to diagnose malignancy in lymphoproliferative diseases. Traditionally, this has been done using Southern blotting, however this technique requires large amounts of high quality DNA, which can not be obtained from FFPE. PCR has been gradually accepted as substitution (Zhou et al., 1999; Arber, 2000; Elenitoba-Johnson et al., 2000; Taheri et al., 2011). This study confirms previous reports that DNA extracted from FFPE can be amplified successfully in most cases. Consentration of extracted DNA in this study were above recommended minimal level (Kitamura et al., 1996).

Amplification of DNA was done successfully in all samples, positive and negative control. A monoclonal band was seen in 18 samples of group I categorized as lymphoma, indicating sensitifity of $90 \%$ for the PCR using two primers, with $10 \%$ of false negative. These result was accordance with the different studies using the same method and primers (Amara et al., 2006; Taheri et al., 2011). Some factors that can cause false negative are: somatic hypermutation, deletion, or chromosomal translocation involving IgH locus, which often occur in mature lymphoma from GC and post GC (Arber, 2000; Amara et al., 2006; Taheri et al., 2011).

A monoclonal band also found in 2 cases in group 2 categorized as reactive process, indicating $60 \%$ specificity of PCR. False positive results or a pseudomonoclonal (non reproducible band) are often occured in a small or microdisecction specimens, because of the little amount of B cell targets. According to Elenitoba et al., polyclonal results were reliably obtained when quantity of template DNA was $50 \mathrm{ng}$ or more (Elenitoba et al., 2000). Thus, a sufficient number of lymphocytes must be present in a sample to allow the productions of heterogeneous $\operatorname{IgH}$ products in order to produce a polyclonal pattern. An alterntive explanation was thatthe fragments might include local clusters of clonal or clonally related cells, which might give dominant band on amplification (Zhou et al., 1999). To avoid false positive results and misdiagnosis in non-malignant reactive processes, it is important compare PCR result with clinical data, histopathological interpretation and IHC staningresult (Elenitoba et al., 2000; Braunschweig et al., 2003).

Group III which was categorized as undetermined group, all cases produced a monoclonal band. Based on morphological features all observers agreed that the diagnosis of those 3 cases were lymphoma, but the IHC result was difficult to be interpretted. Accordance with previous report, there were some undetermined cases couldn't be diagnosed by histopathology and IHC examination turned out to be definitively diagnosed as lymphoma by PCR (Kitamura et al., 1996). Thus, clonality analysis of rearrangement $\mathrm{IgH}$ gene can be used to establish definitive diagnosis in an undetermined IHC result.

In conclusion, this present study reveals a substantial agreement among pathologists on small B-cell NHL diagnosis. On difficult cases, PCR can be useful as complementary technique to morphologic and IHC examinations to establish definitive diagnosis.

\section{Acknowledgements}

This work was financially supported by Dana Masyarakat UGM 2013. 


\section{References}

Amara K, Trimeche M,Ziadi S, et al (2006). PCR-based clonality analysis of B-cell lymphomas in paraffin-embedded tissue: Diagnostic value of immunoglobulin $x$ and $\lambda$ light chain gene rearrangement investigation. Pathol Res Pract, 202, 425-31.

Arber DA (2000) Molecular Diagnostic Approach to NonHodgkin's Lymphoma. J Mol Diagn, 2, 178-190.

Braunschweig R, Baur AS, Delcretaz F, et al (2003). Contribution of IgH-PCR to the evaluation of b-cell lymphoma involvement in paraffin-embedded bone marrow biopsy specimens. Am J Clin Pathol, 119, 634-42.

Campo E, Jaffe ES, Harris NL (2011). Normal lymphoid organs and tissue, in haematopathology. Saunders Elsevier, Philadelphia. 97-117.

El-Zimaity HMT, Wotherspoon A, Jong D (2005). Interobserver variation in the histopathological assessment of malt $/ \mathrm{malt}$ lymphoma: towards a consensus. Blood Cells Mol Dis, 34, 6-16.

Elenitoba-Johnson KS, Bohling SD, Mitchell RS, et al (2000). PCR Analysis of the Immunoglobulin Heavy Chain Gene in Polyclonal Proceses Can Yield Pseudoclonal Bands as an Artifact of Low B Cell Number. J Mol Diagn, 2, 92-6.

Farmer PL, Bailey DJ, Burns BF, et al (2007). The reliability of lymphoma diagnosis in small tissue samples is heavily influenced by lymphoma subtype. Am J Pathol, 128, 474480.

Ferlay J, Steliarova-Foucher E, Lortet-Tieulent J, et al (2013). Cancer Incidence and Mortality Pattern in Europe: estimates for 40 countries in 2012. Eur J Cancer, 49,1374-403.

Hsi ED and Schnitzer B (2011). The Reactive Lymphadenopathies in Haematopathology.Saunders Elsevier, Philadelphia. pp118-139.

Ishtiaq S, Hassan U, Mushtaq S, et al (2013). Determination of frequency of Epstein-Barr virus in non-Hodgkin lymphomas using EBV latent membrane protein 1 (EBV-LMP1) immunohistochemical staining. Asian Pac J Cancer Prev, 14, 3963-67.

Iwamuro M, Okada H, Takata K, et al (2014). Diagnostic accuracy of endoscopic biopsies for the diagnosis of gastrointestinal follicular lymphoma: a clinicopathologic of 48 patiens. Ann Diagn Pathol, 18, 99-103.

Jaffe ES, Harris NL, Stein H, et al (2008). Pathology and genetics of tumours of hematopoietic and lymphoid tissues, in: $W H O$ Classification of Tumours, France: IARC Press. Lyon, 166.

Kitamura Y, Nanba E, Inui S, et al (1996). Diagnosis of lymphoma in paraffin wax sections by nested PCR and immunohistochemistry. J Clin Pathol, 49, 333-37.

Langerak AW, Groenen PJTA,Bruggemann M, et al (2012). EuroClonality/BIOMED-2 guidelines for interpretation and reporting of $\mathrm{Ig} / \mathrm{TCR}$ clonality testing in suspected lymphoproliferations. Leukemia, 26, 2159-71.

Pongpruttipan T, Sukpanichnant S, Assanasen T, et al (2014). Interobserver variation in classifying lymphomas among hematopathologist. Diagn Pathol, 9, 162.

Rizzo K, Nassiri M (2012). Diagnostic Workup of Small B Cell Lymphoma: A Laboratory Perspective. Lymphoma, 2012, 1-15.

Rosai J (2011). Lymph nodes, in surgical pathology. saunders elsevier, Philadelphia. 1778-86.

Sader-Ghorra C, Rassy M, Naderi S, et al (2014). Type distribution of lymphomas in lebanon: five-year single institution experience. Asian Pac J Cancer Prev, 15, 582528.

Taheri ZM,Ziazi LM, Dorudinia A, et al (2011). Clonality of the immunoglobulin heavy chain genes in B cell non-Hodgkin lymphoma using semi-nested PCR. Tanaffos, 10, 25-31.
DOI:http://dx.doi.org/10.7314/APJCP.2016.17.2.491

PCR in Diagnosis of Small B-Cell Non-Hodgkins Lymphomas

Viera AJ and Garrett JM (2005). Understanding interobserver agreemnet: The happa statistic. Fam Med, 379, 360-3.

Werner M, Chott A, Fabiano A, et al (2000). Effect of formalin tissue fixation and processing on immunohistochemistry. Am J Surg Pathol, 24, 1016-19.

Xie R, Chung JY, Ylaya K, et al (2011). Factors influencing the degradation of archival formalin-fixed parrafin-embedded tissue sections. J Histochem Cytochem, 59, 356-65.

Zhou XG, Sandvej K, Gregersen N, et al (1999). Detection of clonal b cells in microdissected reactive lymphoproliferations: possible diagnostic pitfalls in pcr analysis of immunoglobulin heavy chain gene rearrangement. Mol Pathol, 52, 104-10.

Zekri ARN, Hassan ZK, Bahnassy AA, et al (2013). Gene expression profiling of non-Hodgkin lymphomas. Asian Pac J Cancer Prev, 14, 4393-98. 